\title{
Preliminary Investigations in Giant Taro (Alocasia macrorrhiza L.) Corm Meal as Energy Source in Poultry Diets ${ }^{+}$
}

\author{
Siaka Diarra \\ School of Agriculture and Food Technology, University of The South Pacific, PMBag Alafua Apia, Samoa; \\ diarra_s@usp.ac.fj \\ † Presented at the Third International Tropical Agriculture Conference (TROPAG 2019), Brisbane, Australia, \\ 11-13 November 2019.
}

Published: 8 April 2020

\begin{abstract}
Giant taro (Alocasia macrorrhiza var. Tonga) grows wild in Pacific Island countries and has become invasive in most countries. Proximate analysis of giant taro (GT) corm at USP Alafua Central Laboratory showed $\sim 12 \mathrm{MJ}$ ME $/ \mathrm{kg}, 127 \mathrm{~g}$ crude protein $/ \mathrm{kg}$ DM. Currently however, the crop has low food value in the region and its use in poultry feeding is still limited because of the acrid taste due to the presence of calcium (Ca) oxalate. Two preliminary studies (PS) were conducted to evaluate the feeding value of GT for poultry. Study 1 investigated the effect of coconut oil addition on the utilsation of GT corm meal by layers and broilers. Replacing dietary maize with whole GT corm meal at $200 \mathrm{~g} / \mathrm{kg}$ adversely affected performance of broilers and layers $(\mathrm{P}<0.05)$. Addition of coconut oil at 9:1 (corm meal: oil) improved utilisation of the meal by laying hens but not in broilers. Study 2 investigated the effect of peeling and inorganic calcium addition on the utilisation of GT corm meal by laying hens. Results showed that feeding whole GT corm meal at $200 \mathrm{~g} / \mathrm{kg}$ diet had adverse effects on egg production and egg qualities $(\mathrm{P}<0.05)$ but peeling or increasing dietary $\mathrm{Ca}$ carbonate level from 40 to $60 \mathrm{~g} / \mathrm{kg}$ improved the utilisation of whole or peeled corm in terms of egg production and egg qualities. In view of the ready availability and low food value, more research is recommended into processing and diet formulation to improve the utilsation of GT corm meal by poultry.
\end{abstract}

Keywords: feed processing; poultry feeding; underutilised resources

Conflicts of Interest: The authors declare no conflict of interest.

(C) 2020 by the authors. Licensee MDPI, Basel, Switzerland. This article is an open access article distributed under the terms and conditions of the Creative Commons Attribution (CC BY) license (http://creativecommons.org/licenses/by/4.0/). 